\title{
Assessment of Blood Lead Levels and Associated Risk Factors Among Children in Ulaanbaatar, Mongolia
}

\author{
Meredith L Praamsma ${ }^{1}$, Nasantogtokh Ganbaatar ${ }^{1}$, Munkhtsetseg Tsogtbaatar ${ }^{1}$, Elnura Halmambetova ${ }^{2}$, \\ Enkhzol Malchinkhuu ${ }^{3}$, Chimedsuren Ochir', Ganchimeg Ulziibayar'5 ${ }^{5}$ Purevdorj B Olkhanud'
}

'Department of Environmental Health, School of Public Health, Mongolian National University of Medical Sciences, Ulaanbaatar, Mongolia; ${ }^{2}$ Department of Health Sciences, Vrije Universiteit University, Amsterdam, Netherlands; ${ }^{3}$ Department of Pediatrics, School of Medicine, Mongolian National University of Medical Sciences, Ulaanbaatar, Mongolia; ${ }^{4} S$ chool of Public Health, Mongolian National University of Medical Sciences, Ulaanbaatar, Mongolia; ${ }^{5}$ Department, National Center for Public Health, Ulaanbaatar, Mongolia

Submitted: October 2, 2015

Revised: March 29, 2016

Accepted: April 5, 2016

Corresponding Author Purevdorj B Olkhanud, MD, MPH, PhD Department of Environmental Health, School of Public Health, Mongolian National University of Medical Sciences, S. Zorig Street 3 , Ulaanbaatar 14210, Mongolia.

Tel: +976-9919-1661

E-mail: purevdorj@mnumns.edu.mn
Objectives: The objectives of this study were to determine BLLs with a LeadCare II analyzer in children living in Ulaanbaatar, Mongolia and to identify potential risk factors influencing their BLLs with a lifestyle and residential environment questionnaire. Methods: A total of 153 children aged 6-8 years old were tested in 2014. Results: The geometric mean BLL was $5.3 \mu \mathrm{g} / \mathrm{dL}$ ( $95 \% \mathrm{Cl}: 4.9-5.7 \mu \mathrm{g} / \mathrm{dL}$ ) and $69.3 \%$ of the children had blood lead levels $\geq 5 \mu \mathrm{g} / \mathrm{dL}$ (the United States Centers for Disease Control and Prevention's current reference level). Factors that were significant $(p<0.05)$ predictors of $B L L$ in a multiple linear regression model were sex, age, father's education level, and father's job type. The BLL from this study in 2014 shows a 60\% decrease since a prior 2005 study, likely due to the ban on leaded gasoline in the country. Conclusion: Academic performance was significantly influenced by BLL, indicating that actions still need to be taken to reduce lead exposure in Ulaanbaatar.

Keywords: Air Pollution, Environmental Monitoring, Child, Lead, Mongolia

This is an Open Access article distributed under the terms of the Creative Commons Attribution Non-Commercial License (http:// creativecommons.org/licenses/bync/4.0/) which permits unrestricted non-commercial use, distribution, and reproduction in any medium, provided the original work is properly cited. Copyright $\odot 2016$ Mongolian National University of Medical Sciences

\section{Introduction}

Mongolia, a country landlocked between China and Russia and home to one of the world's last remaining pastoral nomads, has seen much change since the transition to a market economy in the early 1990s. Two main changes have been the expansion of the mining industry and the rapid population growth in the capital city, Ulaanbaatar, which increased over 30\% during the 
10-year period from 2004 to 2014 [1, 2]. Economic growth corresponded with these expansions, but so did threats to the health of the population and the environment. One of the most pressing public health threats has become the air pollution in Ulaanbaatar. The daily average concentrations of $\mathrm{PM}_{10^{\prime}} \mathrm{PM}_{2.5^{\prime}}$ and $\mathrm{SO}_{2}$ are above the World Health Organization (WHO) guidelines for at least 9 months of the year, with peaks of daily averages reaching levels that are 6-10 times the WHO guidelines [3]. It has been estimated that $40 \%$ of lung cancer deaths and $29 \%$ of cardiopulmonary deaths of those over age 30 in Ulaanbaatar are attributable to outdoor air pollution, which would account for $9.7 \%$ of total deaths in Ulaanbaatar [3]. Another study showed that the number of spontaneous abortions increased three-fold in winter compared to summer in 2011, which correlated with the increased level of air pollution [4].

Partly due to lack of laboratory capacity and funding in the country, however, the number of studies investigating environmental exposures and their health effects in Mongolia is very few. Even a test such as that of blood lead, which is now routine in the developed world, is difficult to perform in Mongolia and as a result, blood lead levels (BLL) of the population have not been consistently monitored. Despite all of the knowledge of the harm to the renal systems, reproductive systems, physical growth, and mental development of children [5], the WHO estimates that still 600,000 new cases of childhood intellectual disability develop and 143,000 deaths occur each year worldwide because of lead exposure [6]. In Mongolia, the BLL of children was previously assessed at two points in time. In 1999, the average BLL of 120 children aged 6 months to 6 years in Ulaanbaatar was reported as $0.75 \pm 0.07 \mu \mathrm{g} / \mathrm{dL}[7,8]$. In September 2005, 120 children aged 7 to 14 in Ulaanbaatar had an average BLL of $16.54 \pm 9.50 \mu \mathrm{g} / \mathrm{dL}[9,10]$. Although some variation could be caused by different age groups tested in these studies, this cannot fully explain the drastically different results. Both studies also reported lead concentrations in snow, soil, and air. In 1999 and 2005, lead concentrations were 0.042 $\pm 0.007 \mathrm{mg} / \mathrm{m}^{3}$ and $0.064 \pm 0.043 \mathrm{mg} / \mathrm{L}$ in snow, $91.88 \pm 4.49$ $\mathrm{mg} / \mathrm{kg}$ and $41.7 \pm 18.03 \mathrm{mg} / \mathrm{kg}$ in soil, and $2.34 \pm 0.2 \mathrm{mg} / \mathrm{m}^{3}$ and $0.0015 \pm 0.0005 \mathrm{mg} / \mathrm{m}^{3}$ in air, respectively [7-10]. According to this data, the soil and air lead concentrations were higher in 1999 than 2005, yet the blood lead levels were 10-fold lower.

In light of these discrepancies, which may have been partially due to errors, we sought to conduct a follow-up study 9.5 years after the most recent 2005 study and 15 years after the 1999 study. We modeled our questionnaire after the 2005 study in order to see how exposures have changed since then. Because suitable advanced analytical methods were not readily available in Mongolia for the determination of lead in blood at the time of our study, we decided to use the LeadCare II instrument. This instrument has a range of 3.3 to $65.0 \mu \mathrm{g} / \mathrm{dL}$, precision of $\pm 0.64 \mu \mathrm{g} / \mathrm{dL}$ at $5.3 \mu \mathrm{g} / \mathrm{dL}$ and $\pm 0.83 \mu \mathrm{g} / \mathrm{dL}$ at $11.0 \mu \mathrm{g} / \mathrm{dL}$ and good agreement with graphite furnace atomic absorption spectrometry [11]. These specifications were adequate for our purposes and allowed us to use a low-cost, simple method to quantify the BLL in Ulaanbaatar children in 2014.

\section{Materials and Methods}

\section{Study population}

School children in Ulaanbaatar, Mongolia were chosen as the study population due to their increased sensitivity to lead exposure. Students were tested at their schools because of the convenience of testing the children at a common location. Four elementary schools (School \#16, 23, 43, or 79) were selected for our study based on their geographical locations within Ulaanbaatar so that different areas of the city could be assessed. We wanted to assess different areas due to the differing levels of air pollution throughout the city. A map of the school locations is shown in Figure 1. The areas of the city where the traditional dwellings, or gers, are located are depicted in dark grey color in this figure. A ger is a round, portable, felt-covered traditional dwelling structure (i.e., yurt) that is heated with a stove, and ger districts with little infrastructure are located at the outskirts of urban areas including Ulaanbaatar. Figure 1 shows that two of the schools are located in ger areas, where environmental exposures may be higher due to residents living in poorer conditions and burning coal within their homes. Although no air pollution data was collected in this study, average levels of air pollutants are known from previous studies. One researcher modeled the average annual $\mathrm{PM}_{2.5}$ concentrations in Ulaanbaatar, and this data showed that the locations of the schools in our study are all within a zone that has annual averages of at least $150 \mu \mathrm{g} / \mathrm{m}^{3}$ [12], which is 15 times the WHO limit [13]. 


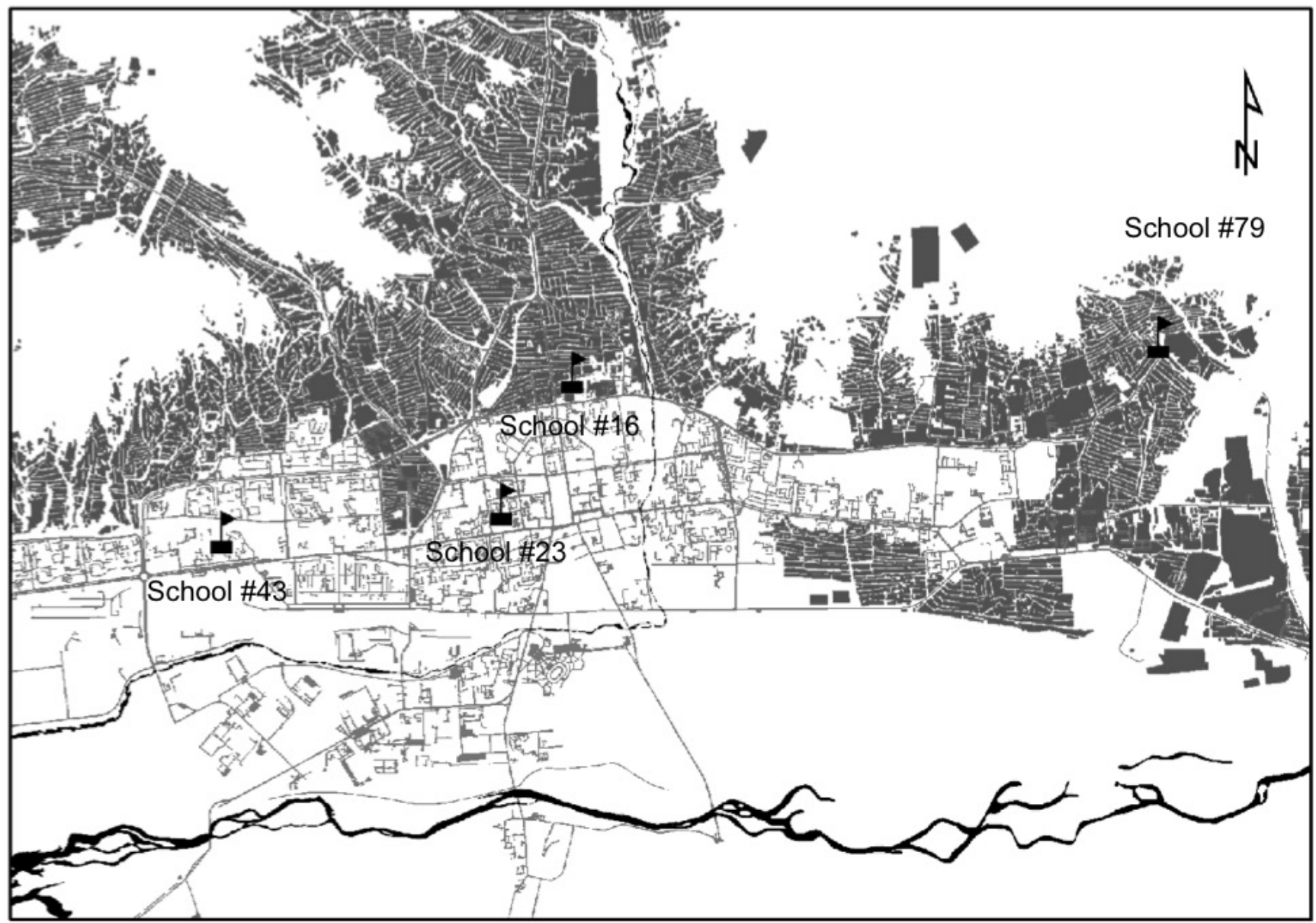

\section{Legend}

I School Major roads $\square$ Ger area $\square$ River

Figure 1. Map of Ulaanbaatar showing the locations of the schools where children were tested.

A total of 153 children were tested. The inclusion criteria for each child were that he or she attended one of the four selected elementary schools and that his or her age was between 6 and 8. Children included in the study were randomly selected from each school to ensure the absence of selection bias. The study was conducted from February 2014 to March 2014 in order to coincide with the winter heating season (November to March) in the city.

\section{Ethics}

The IRB Committee of the Mongolian National University of Medical Sciences approved the study protocol (\#13-04/1A, approved on 12/20/2013). The parents or guardians of all children provided written informed consent after receiving detailed explanations of the study and potential consequences prior to enrollment.

\section{Measurements}

The BLL and anthropomorphic measurements (height and weight) of each child were measured on-site. For BLL measurement, capillary blood was tested using the LeadCare II (ESA Biosciences, Inc., Chelmsford, MA, USA). The LeadCare II is a point-of-care blood lead screening device. Although other methods, such as graphite furnace atomic absorption or inductively coupled plasma mass spectrometry, can provide more accurate and precise results than the LeadCare II, the LeadCare II was used in this study in the absence of these other options for lead testing in Mongolia. 


\section{Questionnaire survey}

Parents of the children were requested to fill out a structured questionnaire with five sections: general information (6 questions), parents' information (6 questions), home environment (13 questions), child's information (14 questions), and external environment (3 questions). Beyond general information, each question was asked to gain insight into possible lead exposures of the parents and children. The questions were selected based on a previous study conducted in Mongolia [10].

A second questionnaire was filled out by each student's teacher. The questionnaire included three sections: school performance, participation in class, and classroom behavior. School performance was rated based on the student's grades. Classroom behavior of the children was also evaluated, however, this assessment was considered to be inadequate and inconsistent to be used in the analysis.

A total of 160 questionnaires were collected, but 7 were incomplete, leaving 153 that were included in the study results. Each question was coded as a numeric score variable.

\section{Statistical analyses}

The dependent variable in this study is BLL. The BLL data were log transformed for comparative analyses since they were nonnormally distributed. In order to explore the effect of the various explanatory variables on BLL, children were divided into 2 groups: those with $B L L \geq 5 \mu \mathrm{g} / \mathrm{dL}$ and $\mathrm{BLL}<5 \mu \mathrm{g} / \mathrm{dL}$. A value of 5 $\mu \mathrm{g} / \mathrm{dL}$ was chosen to divide the groups on account of the United States Centers for Disease Control and Prevention's recent shift from a BLL of concern of $10 \mu \mathrm{g} / \mathrm{dL}$ to a reference value of $5 \mu \mathrm{g} / \mathrm{dL}$ [14]. The $5-\mu \mathrm{g} / \mathrm{dL}$ cutoff is indicative of children who have higher exposure to lead in the United States and was also applied as a guideline for our study in Mongolia. Fifteen children (9.8\% of total) had BLL $<3.3 \mu \mathrm{g} / \mathrm{dL}$ detection limit. For these cases, a value of $1.65 \mu \mathrm{g} / \mathrm{dL}$ was used in statistical calculations.

Independent-sample t-test was used for testing the difference of numeric variables, while Chi-squared test was used for categorical data between the two groups of children, and an ANOVA was used for testing significant differences in BLLs between three or more categories. An odds ratio comparing the two groups of $B L L \geq 5 \mu \mathrm{g} / \mathrm{dL}$ and $B L L<5 \mu \mathrm{g} / \mathrm{dL}$ between males and females was calculated using a Chi-squared test. A multiple linear regression model was estimated using all general child and parent characteristics, behavioral habits, and environmental factors. STATA $®$ software 12.0 (StataCorp, LP, College Station, TX, USA) was used for statistical analysis. A $p$-value $<0.05$ was considered to be statistically significant.

\section{Results}

Overall, the geometric mean BLL of 153 children in Ulaanbaatar was $5.3 \mu \mathrm{g} / \mathrm{dL}(95 \% \mathrm{Cl}: 4.9-5.7 \mu \mathrm{g} / \mathrm{dL})$, while the arithmetic mean $\pm S D$ was $6.0 \pm 2.9 \mu \mathrm{g} / \mathrm{dL}$ (range: $1.65-15.0 \mu \mathrm{g} / \mathrm{dL}$ ) and $69.3 \%$ of the children had blood lead levels $\geq 5 \mu \mathrm{g} / \mathrm{dL}$. General characteristics of the children and parents and their effect on BLL are shown in Table 1. Males comprised a larger proportion of the sample population versus females, at $n=85$ and $n=68$, respectively. Males significantly more often had BLL $\geq 5 \mu \mathrm{g} / \mathrm{dL}$ than females. An odds ratio shows that males are 2.45 times more likely to have a BLL $\geq 5 \mu \mathrm{g} / \mathrm{dL}$ than females $(p=0.017)$. Most of the children $(n=94)$ were age 7 , while only $n=32$ were age 6 and $n=27$ were age 8 . There was a significant difference in BLL between the ages, with the number of BLL $\geq 5$ $\mu \mathrm{g} / \mathrm{dL}$ increasing with age. These trends of differences in sex and age are also shown in Figure 2. Regarding parents, the father's education level and job type were significantly different between groups. Fathers who had less education had children with more $\mathrm{BLL} \geq 5 \mu \mathrm{g} / \mathrm{dL}$ and fathers who worked in jobs with high expected lead exposure had children with more BLL $\geq 5 \mu \mathrm{g} / \mathrm{dL}$.

The influence of behavioral habits on BLLs is shown in Table 2. There were no significant differences in BLLs based on these behavioral habits except academic performance. Students with average or below average academic performance significantly more often had BLL $\geq 5 \mu \mathrm{g} / \mathrm{dL}$ than students with excellent or good academic performance. The differences in BLL between academic groups is shown in Figure 3 .

Table 3 highlights environmental factors that could lead to differences in BLLs. In this case, the school, type of dwelling, presence of a stove, and toy material type led to significant differences between $\mathrm{BLL}<5 \mu \mathrm{g} / \mathrm{dL}$ and $\mathrm{BLL} \geq 5 \mu \mathrm{g} / \mathrm{dL}$ groups. Children attending Schools \#16 and 43 more often had BLL $\geq 5 \mu \mathrm{g} / \mathrm{dL}$ than those attending Schools \#79 and 23. Children living in non-apartment dwellings had more BLL $\geq 5 \mu \mathrm{g} / \mathrm{dL}$ than children living in apartments. Children with a stove in the home had more BLL $\geq 5 \mu \mathrm{g} / \mathrm{dL}$ than children living without a stove, but the type of stove made no difference. Children who played with metal, wood, or plastic toys more often had BLL $\geq 5$ 
Table 1. General characteristics of the children and parents included in the study in relation to children's BLL

\begin{tabular}{|c|c|c|c|c|c|c|c|}
\hline \multirow[t]{2}{*}{ Characteristic } & \multicolumn{2}{|c|}{$\begin{array}{c}\text { BLL } \\
(n=153)\end{array}$} & \multicolumn{2}{|c|}{$\begin{array}{c}\text { BLL }<5 \mu \mathrm{g} / \mathrm{dL} \\
(\mathrm{n}=47)\end{array}$} & \multicolumn{2}{|c|}{$\begin{array}{c}\text { BLL } \geq 5 \mu \mathrm{g} / \mathrm{dL} \\
(\mathrm{n}=106)\end{array}$} & \multirow[t]{2}{*}{ p-value } \\
\hline & $\begin{array}{c}\text { Geometric mean } \\
(\mu \mathrm{g} / \mathrm{dL})\end{array}$ & $\begin{array}{l}95 \% \mathrm{Cl} \\
(\mu \mathrm{g} / \mathrm{dL})\end{array}$ & $\mathbf{n}$ & $\%$ & $\mathbf{n}$ & $\%$ & \\
\hline Child's sex & & & & & & & 0.017 \\
\hline Male & 6.4 & 5.8-7.2 & 14 & 20.6 & 54 & 79.4 & \\
\hline Female & 4.5 & $4.0-5.0$ & 33 & 38.8 & 52 & 61.2 & \\
\hline Child's age & & & & & & & 0.003 \\
\hline 6 & 4.2 & $3.4-5.2$ & 13 & 40.6 & 19 & 59.4 & \\
\hline 7 & 5.4 & 4.8-5.9 & 29 & 30.9 & 65 & 69.1 & \\
\hline 8 & 6.6 & $5.7-7.7$ & 5 & 18.5 & 22 & 81.5 & \\
\hline Father's education level & & & & & & & 0.031 \\
\hline High school & 6.6 & $5.8-7.6$ & 5 & 16.7 & 25 & 83.3 & \\
\hline Trade school & 5.2 & $4.5-6.0$ & 19 & 32.8 & 39 & 67.2 & \\
\hline University & 4.9 & $4.3-5.7$ & 18 & 34.0 & 35 & 66.0 & \\
\hline Mother's education level & & & & & & & 0.119 \\
\hline High school & 5.9 & $5.0-7.0$ & 4 & 16.7 & 20 & 83.3 & \\
\hline Trade school & 5.6 & $4.9-6.4$ & 19 & 31.2 & 42 & 68.8 & \\
\hline University & 4.8 & $4.2-5.5$ & 23 & 35.4 & 42 & 64.6 & \\
\hline Father's job type & & & & & & & 0.009 \\
\hline Low expected lead exposure & 5.0 & $4.5-5.5$ & 33 & 33.7 & 65 & 66.3 & \\
\hline High expected lead exposure & 6.4 & $5.5-7.4$ & 9 & 23.1 & 30 & 76.9 & \\
\hline Mother's job type & & & & & & & 0.607 \\
\hline Low expected lead exposure & 5.2 & $4.8-5.7$ & 42 & 31.8 & 90 & 68.2 & \\
\hline High expected lead exposure & 5.6 & $4.2-7.6$ & 4 & 28.6 & 10 & 71.4 & \\
\hline Monthly household income (MNT) a & & & & & & & 0.253 \\
\hline$<500,000$ & 5.7 & $4.9-6.5$ & 13 & 23.6 & 42 & 76.4 & \\
\hline $500,000-1,000,000$ & 5.3 & $4.7-6.0$ & 18 & 30.5 & 41 & 69.5 & \\
\hline $1,000,001-1,500,000$ & 4.3 & $3.1-5.9$ & 10 & 58.8 & 7 & 41.2 & \\
\hline$>1,500,000$ & 5.0 & 4.0-6.4 & 6 & 27.3 & 16 & 72.7 & \\
\hline
\end{tabular}

${ }^{\mathrm{a}}$ MNT = Mongolian Tugrik

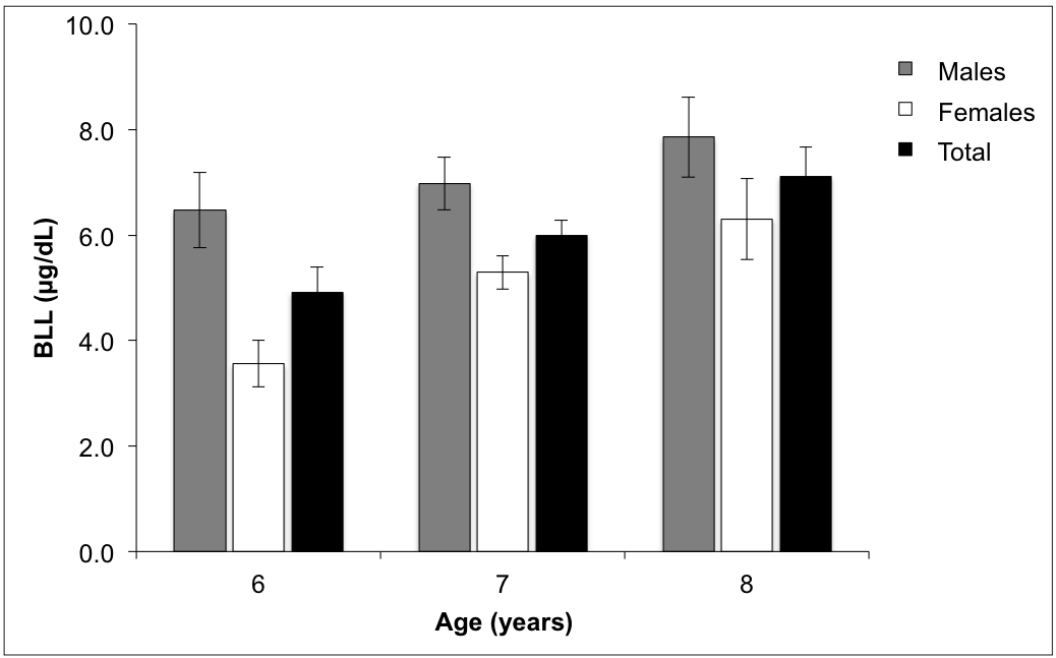

Figure 2. Trend of increasing BLL with age and males having higher BLL than females at each age group. 
Table 2. Behavioral and educational characteristics of the study population in relation to children's BLL

\begin{tabular}{|c|c|c|c|c|c|c|c|}
\hline \multirow[t]{2}{*}{ Characteristic } & \multicolumn{2}{|c|}{$\begin{array}{c}\text { BLL } \\
(n=153)\end{array}$} & \multicolumn{2}{|c|}{$\begin{array}{c}\mathrm{BLL}<5 \mu \mathrm{g} / \mathrm{dL} \\
(\mathrm{n}=47)\end{array}$} & \multicolumn{2}{|c|}{$\begin{array}{c}B L L \geq 5 \mu g / d L \\
(n=106)\end{array}$} & \multirow[t]{2}{*}{$p$-value } \\
\hline & $\begin{array}{c}\text { Geometric } \\
\text { mean }(\mu \mathrm{g} / \mathrm{dL})\end{array}$ & $\begin{array}{l}95 \% \mathrm{Cl} \\
(\mu \mathrm{g} / \mathrm{dL})\end{array}$ & $\mathrm{n}$ & $\%$ & $\mathbf{n}$ & $\%$ & \\
\hline Child eats breakfast regularly & & & & & & & 0.063 \\
\hline No & 5.9 & $5.2-6.6$ & 12 & 24.0 & 38 & 76.0 & \\
\hline Yes & 5.0 & $4.5-5.6$ & 35 & 34.0 & 68 & 66.0 & \\
\hline Child washes hands before eating & & & & & & & 0.794 \\
\hline Always & 5.1 & $4.5-5.9$ & 23 & 34.9 & 43 & 65.1 & \\
\hline Sometimes & 5.4 & $4.8-6.0$ & 22 & 30.6 & 50 & 69.4 & \\
\hline Rarely & 5.6 & $4.5-7.0$ & 2 & 13.3 & 13 & 86.7 & \\
\hline Family eats canned food & & & & & & & 0.117 \\
\hline Always & 4.6 & $3.0-7.1$ & 3 & 30.0 & 7 & 70.0 & \\
\hline Sometimes & 4.9 & $4.4-5.6$ & 28 & 34.1 & 54 & 65.9 & \\
\hline Never & 5.9 & $5.2-6.6$ & 16 & 27.6 & 42 & 72.4 & \\
\hline Family uses Teflon ${ }^{\circledR}$ cookware & & & & & & & 0.989 \\
\hline No & 5.3 & $4.8-5.8$ & 33 & 28.0 & 85 & 72.0 & \\
\hline Yes & 5.2 & $4.8-5.8$ & 14 & 42.4 & 19 & 57.6 & \\
\hline Child is immunized & & & & & & & 0.148 \\
\hline No & 6.6 & $4.4-9.8$ & 1 & 9.1 & 10 & 90.9 & \\
\hline Yes & 5.2 & $4.8-5.7$ & 46 & 32.4 & 96 & 67.6 & \\
\hline Child uses supplements & & & & & & & 0.622 \\
\hline $\mathrm{Fe}$ & 7.6 & 5.3-10.9 & - & - & 3 & 100.0 & \\
\hline Vitamin C & 5.3 & $4.8-5.9$ & 27 & 30.0 & 63 & 70.0 & \\
\hline Vitamin D & 4.9 & $3.4-7.1$ & 3 & 25.0 & 9 & 75.0 & \\
\hline None & 5.2 & $4.4-6.0$ & 17 & 35.4 & 31 & 64.6 & \\
\hline Child's birth weight & & & & & & & 0.886 \\
\hline$<2,500 \mathrm{~g}$ & 5.2 & $3.8-7.2$ & 3 & 27.3 & 8 & 72.7 & \\
\hline $2,501-3,500 \mathrm{~g}$ & 5.3 & 4.7-6.0 & 24 & 29.3 & 58 & 70.7 & \\
\hline$>3,500 \mathrm{~g}$ & 5.2 & $4.6-6.0$ & 20 & 33.3 & 40 & 66.7 & \\
\hline Child attended kindergarten & & & & & & & 0.547 \\
\hline No & 5.6 & $4.2-7.5$ & 6 & 31.6 & 13 & 68.4 & \\
\hline Yes & 5.2 & 4.8-5.7 & 41 & 30.8 & 92 & 69.2 & \\
\hline Parent's knowledge about lead exposure & & & & & & & 0.764 \\
\hline Good & 5.4 & 4.0-7.2 & 5 & 26.3 & 14 & 73.7 & \\
\hline Moderate & 5.0 & $4.4-5.7$ & 16 & 32.7 & 33 & 67.3 & \\
\hline Poor & 5.5 & $4.5-6.8$ & 8 & 29.6 & 19 & 70.4 & \\
\hline None & 5.5 & $4.7-6.4$ & 15 & 27.3 & 40 & 72.7 & \\
\hline Academic performance & & & & & & & 0.019 \\
\hline Excellent & 5.1 & $4.5-5.8$ & 18 & 32.1 & 38 & 67.9 & \\
\hline Good & 4.8 & $4.1-5.5$ & 18 & 32.7 & 37 & 67.3 & \\
\hline Average or below average & 6.4 & $5.4-7.5$ & 11 & 26.2 & 31 & 73.8 & \\
\hline
\end{tabular}


Table 3. Environmental factors in relation to children's BLL

\begin{tabular}{|c|c|c|c|c|c|c|c|}
\hline \multirow[t]{2}{*}{ Factor } & \multicolumn{2}{|c|}{$\begin{array}{c}\text { BLL } \\
(n=153)\end{array}$} & \multicolumn{2}{|c|}{$\begin{array}{c}\mathrm{BLL}<5 \mu \mathrm{g} / \mathrm{dL} \\
(\mathrm{n}=47)\end{array}$} & \multicolumn{2}{|c|}{$\begin{array}{c}B L L \geq 5 \mu g / d L \\
(n=106)\end{array}$} & \multirow[t]{2}{*}{$p$-value } \\
\hline & $\begin{array}{c}\text { Geometric mean } \\
(\mu \mathrm{g} / \mathrm{dL})\end{array}$ & $\begin{array}{l}95 \% \mathrm{Cl} \\
(\mu \mathrm{g} / \mathrm{dL})\end{array}$ & $\mathbf{n}$ & $\%$ & $\mathrm{n}$ & $\%$ & \\
\hline School number & & & & & & & 0.001 \\
\hline 16 & 5.7 & $4.9-6.7$ & 12 & 26.1 & 34 & 73.9 & \\
\hline 23 & 3.7 & $2.9-4.7$ & 16 & 59.3 & 11 & 40.7 & \\
\hline 43 & 5.9 & $5.1-6.9$ & 8 & 19.5 & 33 & 80.5 & \\
\hline 79 & 5.4 & $4.7-6.2$ & 11 & 28.2 & 28 & 71.8 & \\
\hline Residential address & & & & & & & 0.568 \\
\hline Bayangol (BG) & 5.6 & $4.7-6.5$ & 9 & 23.1 & 30 & 76.9 & \\
\hline Bayanzurkh (BZ) & 5.5 & $4.9-6.2$ & 14 & 29.2 & 34 & 70.8 & \\
\hline Sukhbaatar (SB) & 4.8 & $4.1-5.8$ & 18 & 36.7 & 31 & 63.3 & \\
\hline Songinokhairkhan (SK) & 5.4 & $3.9-7.4$ & 47 & 37.5 & 10 & 62.5 & \\
\hline Type of dwelling & & & & & & & 0.047 \\
\hline Apartment & 4.8 & $4.2-5.5$ & 23 & 34.9 & 43 & 65.2 & \\
\hline Non-apartment & 5.7 & $5.1-6.3$ & 24 & 27.6 & 63 & 72.4 & \\
\hline Presence of stove & & & & & & & 0.026 \\
\hline No & 4.8 & $4.1-5.5$ & 25 & 36.2 & 44 & 63.8 & \\
\hline Yes & 5.7 & $5.2-6.3$ & 22 & 26.2 & 62 & 73.8 & \\
\hline Type of stove & & & & & & & 0.491 \\
\hline Traditional & 5.8 & $4.9-6.8$ & 10 & 25.6 & 29 & 73.4 & \\
\hline Improved & 5.5 & $4.8-6.4$ & 8 & 25.0 & 24 & 75.0 & \\
\hline Eco & 6.2 & $4.7-8.1$ & 4 & 28.6 & 10 & 71.4 & \\
\hline Drinking water source & & & & & & & 0.140 \\
\hline Centralized & 5.0 & $4.5-5.6$ & 32 & 36.0 & 57 & 64.0 & \\
\hline Portable & 5.7 & $5.0-6.4$ & 15 & 23.4 & 49 & 76.6 & \\
\hline Smoking family member & & & & & & & 0.825 \\
\hline No & 5.3 & 4.7-5.9 & 18 & 29.5 & 43 & 70.5 & \\
\hline Yes & 5.4 & $4.7-6.1$ & 28 & 31.1 & 62 & 68.9 & \\
\hline Last home renovation & & & & & & & 0.717 \\
\hline$<1$ year ago & 5.1 & 4.5-5.9 & 14 & 29.2 & 34 & 70.8 & \\
\hline $2-3$ years ago & 4.9 & $4.2-5.8$ & 16 & 34.0 & 31 & 66.0 & \\
\hline 4-5 years ago & 4.9 & $3.6-6.7$ & 6 & 37.5 & 10 & 62.5 & \\
\hline$>5$ years ago & 6.4 & $5.5-7.5$ & 9 & 24.3 & 28 & 75.7 & \\
\hline Toy material & & & & & & & 0.019 \\
\hline Non-Cotton (metal, wood, plastic) & 5.2 & $4.8-5.7$ & 20 & 23.0 & 67 & 77.0 & \\
\hline Cotton & 6.3 & 4.6-8.6 & 27 & 40.9 & 39 & 59.1 & \\
\hline Proximity to major roads & & & & & & & 0.843 \\
\hline$<50$ meters & 5.2 & $4.5-6.1$ & 15 & 34.1 & 29 & 65.9 & \\
\hline 51-100 meters & 5.5 & 4.6-6.1 & 11 & 24.4 & 34 & 75.6 & \\
\hline$>100$ meters & 5.2 & $4.6-5.8$ & 21 & 33.3 & 42 & 66.7 & \\
\hline Home near to a gas station & & & & & & & 0.388 \\
\hline No & 5.4 & 4.9-5.9 & 33 & 29.7 & 78 & 70.3 & \\
\hline Yes & 5.0 & $4.2-5.9$ & 14 & 33.3 & 28 & 66.7 & \\
\hline
\end{tabular}


$\mu \mathrm{g} / \mathrm{dL}$ than those who played only with cotton toys. The residential address, drinking water source, smoking inside the home, home renovation, proximity to major roads, and living near a gas station did not significantly affect BLLs.

Applying the multiple linear regression model to all general child and parent characteristics, behavioral habits, and environmental factors generated the results shown in Table 4. The final equation for this model was $\log (B L L)=0.25+0.21$ (age) +0.33 (sex) -0.12 (father's education level) +0.17 (father's job type), revealing that age, sex, father's education level, and father's job type were significant predictors of childhood BLLS in Ulaanbaatar.

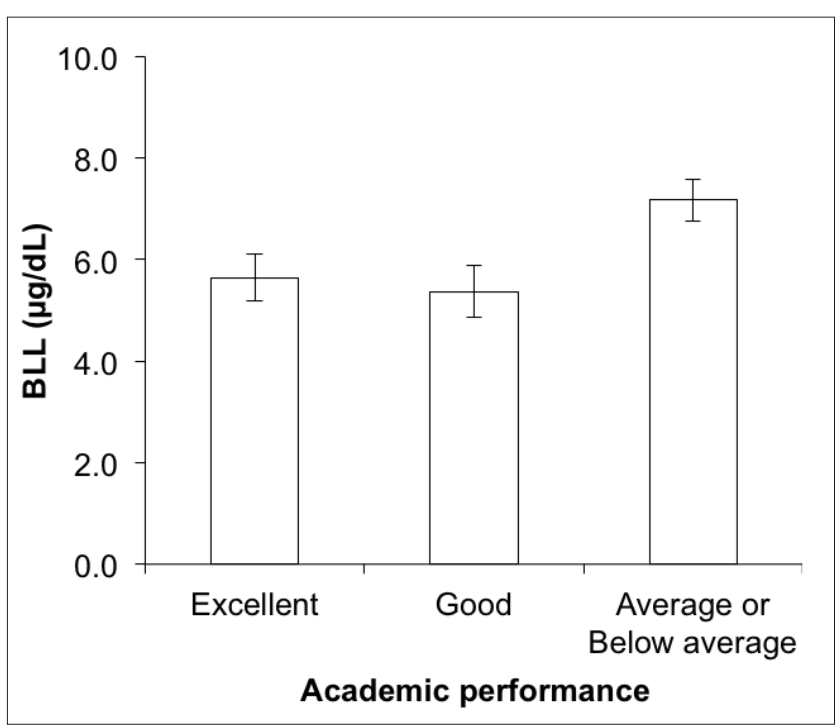

Figure 3. Trend of increasing BLL with decreasing academic performance.

Table 4. Significant variables from all general child and parent characteristics, behavioral habits, and environmental factors using a multiple linear regression model

\begin{tabular}{|c|c|c|c|c|}
\hline Parameter & Coefficient $\left(\beta_{0}\right)$ & $95 \% \mathrm{Cl}\left(\beta_{0}\right)$ & Standard error & $\mathrm{p}$-value \\
\hline Age & 0.21 & $0.09-0.34$ & 0.06 & 0.001 \\
\hline Sex & 0.33 & $0.18-0.48$ & 0.08 & $<0.001$ \\
\hline Father's education level & -0.12 & $-0.22--0.19$ & 0.05 & 0.020 \\
\hline Father's job type & 0.17 & $0.001-0.33$ & 0.08 & 0.048 \\
\hline Constant & 0.25 & $-0.64-1.13$ & 0.45 & - \\
\hline
\end{tabular}

\section{Discussion}

Comparing the results of the current 2014 study to those of the 2005 study shows that BLL in Ulaanbaatar children has dropped dramatically from $16.5 \pm 9.5 \mu \mathrm{g} / \mathrm{dL}[9]$ to $6.0 \pm 2.9 \mu \mathrm{g} / \mathrm{dL}$. The highest BLL from the 2005 study was $75 \mu \mathrm{g} / \mathrm{dL}$ [10], while the highest BLL from the 2014 study was $15.0 \mu \mathrm{g} / \mathrm{dL}$. The biggest contributor to this decrease has probably been the phase-out of leaded gasoline in the country. According to the United Nations Environment Program's Partnership for Clean Fuels and Vehicles, Mongolia still used leaded gasoline as of January 2006, but sometime between January 2008 and December 2008 Mongolia effectively banned leaded gasoline [15, 16]. In 2005, the number of registered vehicles in Ulaanbaatar was 67,361 [1] and since that time, the number has at least tripled [2]. Therefore, if leaded gasoline had not actually been banned, BLLs would not have decreased.
However, from 2005 to 2014, the air pollution in Ulaanbaatar has not decreased. Three coal-fired power plants supplied heat and electricity to $40 \%$ of city residents by burning approximately 3.5 million tons of coal (2006 estimate) [17]. Gers, homes, food kiosks, heat-only boilers, and brick manufacturing plants are also burning coal in significant amounts [12], and Mongolian coal burned in Ulaanbaatar is known to contain lead [18]. Concentrations of lead in $\mathrm{PM}_{10}$ were shown to be higher in the heating season $\left(47.4 \mathrm{ng} / \mathrm{m}^{3}\right)$ versus the non-heating season (13 $\left.\mathrm{ng} / \mathrm{m}^{3}\right)$, therefore the lead in the air is likely associated with coal combustion [19].

In our study, although the environmental factors of school number, type of dwelling, presence of stove, and toy material type had significant differences among their respective groups, they were not significant predictors of BLL in the multiple linear regression model. It has been shown that PM concentrations do change depending on the dwelling type and the neighborhood 
area. For example, in 149 households tested in December 2003 and January 2004 in Ulaanbaatar, average PM $_{10}$ concentrations were $380 \mu \mathrm{g} / \mathrm{m}^{3}$ in apartments, $460 \mu \mathrm{g} / \mathrm{m}^{3}$ in gers, and 900 $\mu \mathrm{g} / \mathrm{m}^{3}$ in houses [20]. Also, concentrations of $\mathrm{PM}_{10}$ have been shown to range from $350-700 \mu \mathrm{g} / \mathrm{m}^{3}$ in ger areas versus 150 $250 \mu \mathrm{g} / \mathrm{m}^{3}$ in central city areas [21]. However, our BLL estimates seem to suggest that no matter where a child lives or attends school in Ulaanbaatar, they are exposed to lead through coal dust in the air.

Children with fathers with lower education and jobs with potential lead exposure have higher lead levels than children whose fathers have higher education and jobs without potential lead exposure. The industries of the fathers' occupation that were specifically inquired about were construction, car repair, gasoline distribution, printing, mining, and heavy machinery. It could be that fathers are bringing lead home on their shoes and clothing thereby exposing their children to lead. A related study in Karachi, Pakistan also reported a higher BLL in children whose fathers worked in risky occupations and had lower education, however, as in our study, the mother's education was not significant [22]. A study in Poland showed that children with parents with occupational lead exposure had higher BLL than children whose parents did not have occupational lead exposure, but they did not investigate the role of education [23]. In both of these studies, the variables were not significant predictors of $B L L$ in the multiple linear regression models $[22,23]$, but they were in our study, indicating that training fathers in these occupations about the dangers of bringing lead to their home should be implemented.

Among the Ulaanbaatar children in this study, males had a higher BLL than females, and a greater percentage of boys had $\mathrm{BLL} \geq 5 \mu \mathrm{g} / \mathrm{dL}$. Also, BLL increased with age and more children had $\mathrm{BLL} \geq 5 \mu \mathrm{g} / \mathrm{dL}$ as age increased from 6 to 8 . There was no trend of increasing BLL with age in the 2005 Mongolian study and females had a higher BLL than males [10]. In China, 18 combined studies from 2001 to 2007 showed that males had statistically significantly higher BLLs than females and that average BLLs increased each year in children from ages 0 to 6 [24]. The results of other studies on children show that males have higher BLL than females $[23,25]$ but it is not always significant [26]. Perhaps the playing habits of male versus female children in Mongolia, i.e., spending more time actively playing outdoors, are leading the males to have higher BLL.
The significant variables influencing child BLL in the 2005 Ulaanbaatar lead study were per capita income and hand washing before meals and after playing outside [10]. However, household income level and hand washing before meals did not give significant differences in BLL in the 2014 study. The current 2014 study had a more thorough questionnaire regarding environmental exposures, but the 2005 study conducted a more thorough medical exam, which showed that irritability, memory deterioration, weakening attention, and lack of interest in studying were significantly related to BLL [10]. The 2014 study only found academic performance to be affected by BLL. This is consistent with other studies that have demonstrated decreased IQ [27] is an effect of lead exposure even at BLL $<10 \mu \mathrm{g} / \mathrm{dL}$, and this finding should encourage actions to further reduce lead levels to protect children's intellectual function.

There are at least four limitations to this study that should be noted. First, a subjective evaluation of the children's academic performance by the teachers was used. While the teachers were not aware of the children's BLL, an assessment such as an IQ test would have been a better measure of the effects of lead on the children's intellectual capacity, but a validated IQ test was not available in Mongolia during the study period. Second, some of the questions on the questionnaire were worded in a way that did not gather the most relevant information. For example, the question on smoking did not specifically ask if the family member smoked within the home. It is known that cigarette smoke increases the BLL of smokers and those exposed to secondhand smoke [28], so the question should have been worded differently to determine the influence of smoking on children's BLL. Third, the only physical parameters measured were height and weight, while a more thorough medical examination could have revealed other areas of health affected by lead exposure. Fourth, environmental samples were not collected to exactly identify sources of lead exposure.

Our study has provided an update on BLL among children in Ulaanbaatar, Mongolia. From 2005 to 2014, the average childhood BLL in Ulaanbaatar has dropped by $\sim 60 \%$, which is attributed to the no longer widespread use of leaded gasoline. However, with an average childhood BLL at $6.0 \pm 2.9 \mu \mathrm{g} / \mathrm{dL}$ in 2014, efforts should still be made to further reduce lead exposure in Mongolia. Decreasing air pollution from coal burning should be one strategy. Educating fathers in occupations with lead exposure should be another strategy, so that lead is 
not brought home to their children. Future studies should focus on testing BLL of fathers in occupations with potential exposure and determining lead in environmental samples near/in children's homes and schools including air, dust, soil, and paint. As more knowledge is gathered about potential exposures, further intervention strategies may be implemented to continue reducing the effects of childhood lead exposure in Mongolia.

\section{Conflict of Interest}

The authors state no conflict of interest.

\section{Acknowledgements}

This work was supported by Avison International Research Grant of the Yonsei University Health System, Korea [grant \# 20140404], the Mongolian Science and Technology Fund of the Ministry of Education and Science, Mongolia [grant \# 05312013], and the National Institute of Environmental Health Sciences, National Institutes of Health, USA [grant \# D43ES022862].

\section{References}

1. National Statistical Office of Mongolia. Mongolian Statistical Yearbook 2005 [accessed on 9 June 2015]. Available at: http://www.mnso.mn.

2. National Statistical Office of Mongolia. Monthly Bulletin of Statistics [accessed on 9 June 2015]. Available at: http:// www.mnso.mn.

3. Allen RW, Gombojav E, Barkhasragchaa B, Byambaa T, Lkhasuren 0 , Amram 0 , et al. An assessment of air pollution and its attributable mortality in Ulaanbaatar, Mongolia. Air Quality, Atmosphere and Health 2013; 6: 137-150.

4. Enkhmaa D, Warburton N, Javzandulam B, Uyanga J, Khishigsuren $Y$, Lodoysamba $S$, et al. Seasonal ambient air pollution correlates strongly with spontaneous abortion in Mongolia. BMC Pregnancy and Childbirth 2014; 14: 1471-2393.

5. Agency for Toxic Substances and Disease Registry. Draft Toxicological Profile for Lead [accessed on 17 June 2015]. Available at: http://www.atsdr.cdc.gov/toxprofiles/ tp.asp?id=96\&tid=22.
6. World Health Organization. Lead Poisoning and Health [accessed on 9 June 2015]. Available at: http://www.who. int/mediacentre/factsheets/fs379/en/.

7. Burmaa B, Dorogova VB, Enkhtsetseg $S$, Erdenechimeg $E$, Enkhjhargal A. Impact of lead-induced environmental pollution on children's health in Mongolia. Gigiena i sanitariia 2002; 2002: 21-23.

8. Burmaa B, Enkhtsetseg $S$, Erdenechimeg E, Batdelger S. Blood lead level in children. In: Burmaajav B and Enkhtsetseg S, ed. Environmental Health Research. Ulaanbaatar, Mongolia: Soyombo Printing Co., Ltd; 2010: 347-361.

9. Dorogova VB, Burmaa B, Enkhtsetseg B, Baigal O, Oiuunbileg $D$, Tsegmid $S$, et al. Environmental lead pollution in Ulan-Bator and children's health. Gigiena i sanitariia. 2008; 2008: 8-9.

10. Burmaa B, Enkhtsetseg S, Baigal O, Oyunbileg D, Tsegmid S, Tuya $S$, et al. Environmental lead pollution in Ulaanbaatar City and its impact on children's health. In: Burmaajav B and Enkhtsetseg S, ed. Environmental Health Research. Ulaanbaatar, Mongolia: Soyombo Printing Co., Ltd; 2010: 362-379.

11. Magellan Diagnostics, Inc. LeadCare $®$ II Blood Lead Test Kit [accessed on 10 August 2015]. Available at: http:// www.leadcare2.com/getmedia/21d1301e-efee-480f9586-128f1dbc568f/80-0052-Package-Insert,-LeadCareII-Test-Kit-v109-Rev02.pdf.aspx.

12. Guttikunda SK, Lodoysamba S, Bulgansaikhan B, Dashdondog B. Particulate pollution in Ulaanbaatar, Mongolia. Particulate pollution in Ulaanbaatar, Mongolia. Air Quality, Atmosphere, and Health 2013; 6: 589-601.

13. World Health Organization. WHO Air quality guidelines for particulate matter, ozone, nitrogen dioxide and sulfur dioxide [accessed on 27 July 2015]. Available at: whqlibdoc.who.int/hq/2006/who_sde_phe_oeh_06.02_ eng.pdf.

14. US Centers for Disease Control and Prevention. New Blood Lead Level Information [accessed on 24 June 2015]. Available at: http://www.cdc.gov/nceh/lead/acclpp/ blood_lead_levels.htm.

15. United Nations Environment Program. Let's Make Leaded Gasoline History Together! [accessed on 10 June 2015]. Available at: http://www.unep.org/transport/pcfv/PDF/ 
Brochurelead.pdf.

16. United Nations Environment Program. Target 2008: Global Elimination of Leaded Petrol [accessed on 10 June 2015]. Available at: http://www.unep.org/transport/pcfv/PDF/ LeadReport-Brochure.pdf.

17. World Bank. Urban Air Pollution Analysis for Ulaanbaatar [accessed on 14 March 2016]. Available at: http://www. forum.mn/res_mat/res_mat-12.pdf.

18. Baimonda D, Bernasconi G, Haselberger N, Markowicz A, Valkovic V. Trace element XRF analysis of Mongolian coals. J Radioanal Nucl Ch 1994; 185: 27-34.

19. Nishikawa M, Matsui I, Batdorj D, Jugder D, Mori I, Shimizu $A$, et al. Chemical composition of urban airborne particulate matter in Ulaanbaatar. Atmos Environ 2011; 45: 5710-5715.

20. Mongolian Ministry of Health. Health risk assessment of indoor air pollution [accessed on 11 June 2015]. Available at: http://moh.mn/moh db/healthreports. e9f3e7452a6f3c8256d1b0013e24e/20d1c924b5ac52fbc8256f0f00818d46/\$FILE/IAQs Final_2004.09.10.pdf.

21. The World Bank. Air quality analysis of Ulaanbaatar improving air quality to reduce health impacts [accessed on 14 March 2016]. Available at: http://www-wds.worldbank.org/external/default/WDSContentServer/WDSP/IB/ 2012/01/16/000386194_20120116025654/Rendered/ PDF/660820v10revis00MongoliaOReport0Web.pdf.
22. Rahbar MH, White F, Agboatwalla M, Hozhabri S, Luby S. Factors associated with elevated blood lead concentrations in children in Karachi, Pakistan. B World Health Organ 2002; 80: 769-775.

23. Jarosińska D, Peddada S, Rogan WJ. Assessment of lead exposure and associated risk factors in urban children in Silesia, Poland. Environ Res 2004; 95: 133-142.

24. He K, Wang S, Zhang J. Blood lead levels of children and its trend in China. Sci Total Environ 2009; 407: 3986-3993.

25. Naicker N, Norris SA, Mathee A, von Schirnding YE, Richter L. Prenatal and adolescent blood lead levels in South Africa: Child, maternal and household risk factors in the Birth to Twenty cohort. Environ Res 2010; 110: 355-362.

26. Olivero-Verbel J, Duarte $D$, Echenique $M$, Guette J, Johnson-Restrepo B, Parsons PJ. Blood lead levels in children aged $5-9$ years living in Cartagena, Colombia. Sci Total Environ 2007; 372: 707-716.

27. Jusko TA, Henderson Jr CR, Lanphear BP, Cory-Slechta DA, Parsons PJ, Canfield RL. Blood lead concentration $<10 \mu \mathrm{g} /$ $\mathrm{dL}$ and child intelligence at 6 years of age. Environ Health Persp 2008; 116: 243-248.

28. Richter PA, Bishop EE, Wang J, Kaufmann R. Trends in tobacco smoke exposure and blood lead levels among youths and adults in the United States: The national health and nutrition examination survey, 1999-2008. Preventing Chronic Disease 2013; 10: 130056. 